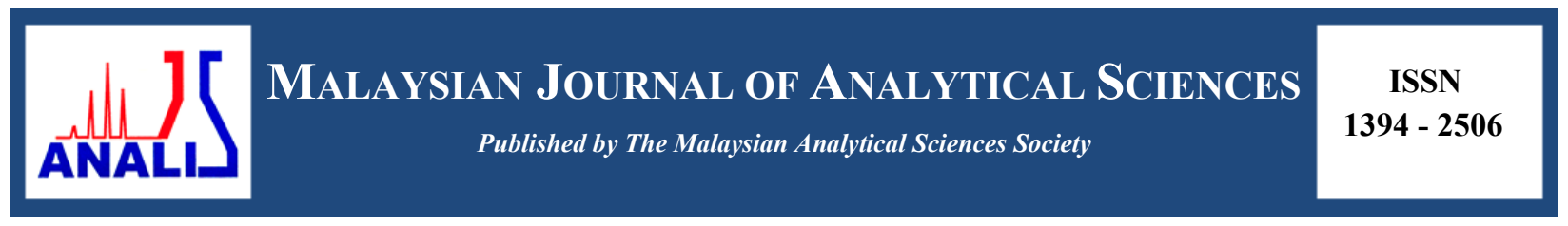

\title{
RESPONSE SURFACE METHODOLOGY OPTIMIZATION OF OIL REMOVAL USING BANANA PEEL AS BIOSORBENT
}

\section{(Pengoptimuman Kaedah Gerak Balas Permukaan Untuk Penyingkiran Minyak Menggunakan Kulit Pisang sebagai Penjerap-Bio)}

\author{
Najaa Syuhada Mohamad Thani ${ }^{1}$, Rozidaini Mohd Ghazi ${ }^{1 *}$, Norhisyam Ismail $^{2}$ \\ ${ }^{I}$ Faculty of Earth Science, \\ Universiti Malaysia Kelantan Jeli Campus, 17600 Jeli, Kelantan, Malaysia \\ ${ }^{2}$ Department of Chemistry, Faculty of Science, \\ Uni versiti Teknologi Malaysia, 81310, Skudai Johor Bharu, Johor, Malaysia \\ *Corresponding author: rozidaini@umk.edu.my
}

Received: 21 February 2017; Accepted: 24 August 2017

\begin{abstract}
Improper waste management of oil causes environmental pollution particularly water pollution. Conventional method in treating oil contaminants are expensive and have low removal efficiency, hence the use of natural adsorbent is suggested because of its reliability and affordability. This study aimed to use banana peel as a biosorbent for oil removal and the application of response surface methodology to identify the optimum conditions of oil removal. The adsorptive capacity of household wastes derived from banana peel towards oil were studied by using different parameters such as oil concentration, adsorbent dosage and contact time. Maximum oil adsorption of $98.86 \%$ was achieved using banana peel. The optimum conditions for oil removal were found at a dosage of $4.94 \mathrm{~g}$, for 10.29 hours contact time and the initial oil concentration as high as $8.74 \%$. The rate of oil adsorption was mathematically described as a function of experimental parameters and was modelled through response surface methodology via Box-Behnken design. The results showed that the responses of oil adsorption were significantly affected by the quadratic term of oil concentration, adsorbent dosage and contact time. The statistical analysis was performed by ANOVA which indicated good correlation of experimental parameters.
\end{abstract}

Keywords: banana peel, oil removal, response surface methodology

\begin{abstract}
Abstrak
Pengurusan sisa minyak yang tidak teratur menyebabkan pencemaran alam sekitar terutamanya pencemaran air. Kaedah konvensional untuk merawat pencemaran minyak adalah mahal dan tahap penyingkiran minyaknya adalah rendah, maka penggunaan penjerap semulajadi adalah dicadangkan kerana kebolehannya menyerap minyak dan lebih menjimatkan. Matlamat kajian ini adalah untuk menggunakan kulit pisang sebagai biopenjerap untuk penyingkiran minyak dan aplikasi kaedah gerak balas permukaan untuk mengenal pasti keadaan optimum kapasiti penyingkiran minyak. Kapasiti penjerapan daripada sisa rumah yang diambil daripada kulit pisang terhadap minyak telah dikaji dengan menggunakan parameter yang berbeza seperti kepekatan minyak, kuantiti penjerap dan tempoh masa. Penjerapan minyak secara maksimum, pada kadar $98.86 \%$ telah dicapai oleh kulit pisang. Keadaan optimum untuk menyingkirkan minyak adalah pada kadar 4.94 g, 10.29 jam dan kepekatan minyak sebanyak $8.74 \%$. Kadar penjerapan minyak telah diterangkan secara matematik dalam fungsi parameter eksperimen dan telah dimodelkan melalui reka bentuk Box-Behnken (kaedah gerak balas permukaan). Hasil kajian menunjukkan bahawa tindak balas penjerapan minyak sangat dipengaruhi oleh kepekatan minyak, kuantiti penjerap dan tempoh masa. Analisis statistik ANOVA menunjukkan korelasi yang baik bagi setiap parameter eksperimen.
\end{abstract}

Kata kunci: kulit pisang, penyingkiran minyak, kaedah gerak balas permukaan 


\section{Introduction}

Water pollution affects not only individual living species, but also populations and entire functioning ecosystems that exist in the water. Oil and grease is toxic to some aquatic organisms. The oil film also prevents oxygen transfer from the atmosphere and causes low dissolved oxygen levels in the water [1]. Cities spend billions of dollars every year unplugging or replacing grease-blocked pipes, repairing pump stations, and cleaning up costly and illegal wastewater spills [2].

Conventional methods to remove oil and grease are the use of skimming tanks, oil and grease traps and interceptors in treatment plants. The main disadvantage of these methods is low efficiency of removal [1]. Biosorption process involves a solid phase (sorbent) and a liquid phase (solvent, normally water) containing a dissolved species to be sorbed (sorbate, e.g. oil). Due to the higher 'affinity' of the sorbent for the sorbate species the latter is attracted into the solid and bound there by different mechanisms [3]. The production of biosorbent will save cost, be environmentally friendly, effective in treating oil pollution, minimization of sludge upon usage and ability of regeneration of biosorbent [4]. Other study for oil removal has been conducted by Vlaev et al. [5], using rice husk ash, where at a given temperature, black rice husk ash sorbed more crude oil than diesel fuel. Hussein et al. [6], studied about carbonized peat bagasse where the result showed that the fibres extracted from bagasse and carbonized at $300{ }^{\circ} \mathrm{C}$ for 2 hours were found to have a high performance for sorption, recovery and recycling of heavy oils, even the viscous ones. Peat-based sorbents has been tested by Cojocaru et al. [7], where the removal efficiency of $99.21 \%$ was achieved. Sawdust has also been tested, where oleic acid grafted sawdust (OGSD) had the best sorption capacity for crude oil as well as weathered oil [8]. In addition, a study on sugarcane bagasse conducted by Brandao et al. [9] showed great potential when it was able to adsorb up to $99 \%$ of oil. Said et al. [10] tested grafted raw bagasse in pure oil, and sorption capacity of $3 \mathrm{~g} / \mathrm{g}$ was achieved after about 15 minutes. A study on vegetable fibres also showed a very high degree of hydrophobicity and oil sorption capacity of approximately $85 \mathrm{~g}$ oil/g sorbent in 24 hours [11].

Response surface methodology (RSM) is an effective statistical technique for optimizing complex processes. It can reduce the number of experimental trials needed to evaluate multiple parameters and their interactions. Moreover, Box-Behnken design (BBD), as a type of response surface design, is also widely used in many research work [12]. RSM is a very effective technique for this study because it presents statistical models which can be used to know the relationship between the parameters that have been optimized [13].

Hence, the goal of this study is to utilize banana peel as a biosorbent for oil removal and the application of RSM to identify the optimum conditions of oil removal. By considering the initial concentration of oil, biosorbent dosage and contact time, a regression model for surface area (response) was developed.

\section{Materials}

\section{Materials and Methods}

Cooking oil was used as a synthetic oil wastewater. The solvent used was n-Hexane (95\% pure, Bendosen). The water used was distilled water that was produced in the Environmental Science Laboratory, Universiti Malaysia Kelantan. Banana peels were collected from a local store in Jeli, Kelantan.

\section{Untreated banana peel (UBP)}

Banana peels were separated from the fruit gently, washed thoroughly with distilled water to remove other inorganic impurities. Then, it was dried under sun light for 5 days and heated using an oven (Model FD115, Binder, Korea) at $70{ }^{\circ} \mathrm{C}$ for 1 hour. The dried banana peels were then cut into small pieces, ground using a blender and sieved with $200-400 \mu \mathrm{m}$.

\section{Treated banana peel (TBP)}

The method was the same with untreated banana peel but the dried banana peel was then treated with $0.5 \mathrm{M}$ hydrochloric acid for 24 hours at speed rate of $4 \mathrm{rpm}$. The modified banana peel was washed several times with deionized water to remove any excess acid. It was dried for 24 hours at $60{ }^{\circ} \mathrm{C}$ in an oven before starting the experiments. 


\section{Biosorption studies}

Different biosorption studies were carried out for contact time, biosorbent dosage and oil concentration, and how the parameters influenced the biosorption process, all of this was performed at room temperature.

The experiments were conducted in a 250 -ml conical flask containing $100 \mathrm{ml}$ of synthetic oil wastewater (oil-inwater mixture). The sample was prepared by mixing cooking oil and distilled water using a blender following the desired concentrations. The synthetic oil wastewater with different percentages was treated differently with various quantities of biosorbent for a desired time, in an incubated shaker at a speed of $150 \mathrm{rpm}$.

At the end of the treatment, the biosorbent was removed from the oil and water mixture by passing it through cloth coffee filters. The concentration of oil before and after treatment was calculated using gravimetric method. The control experiment was the flask without biosorbent.

\section{Gravimetric-based methods}

$100 \mathrm{ml}$ of synthetic oil wastewater was added in a clean separatory funnel. The acidity of the sample was adjusted at $\mathrm{pH} 2$ or less by adding $4 \mathrm{ml}$ hydrochloric acid solution, $6.0 \mathrm{~N}(1: 1)$. It was then serially extracted three times with $\mathrm{n}$ hexane in a separatory funnel.

After separating the solvent (now containing oil) from the water sample, it was placed into a round bottom flask, which has been weighed beforehand. It then underwent a distillation process to remove n-hexane. After that, the flask was placed in an oven for 12 hours at $106{ }^{\circ} \mathrm{C}$ to evaporate excess water. After the solvent was evaporated, the flask now containing the residual oil is dried and weighed. Knowing the weight of the empty flask, the amount of residual oil can be calculated [14].

\section{Screening of biosorbent}

The experiments were conducted in a $250-\mathrm{ml}$ conical flask containing $100 \mathrm{ml}$ of 1:1 ratio oil and water mixture, prepared by mixing cooking oil with distilled water using a blender and its $\mathrm{pH}$ was measured.

The synthetic oil wastewater with $50 \% \mathrm{w} / \mathrm{v}$ concentration was treated with $0.5 \mathrm{~g}$ of UBP and TBP for 3 hours, in an orbital shaker (Model SI-300/300R/600/600R, JEIO TECH, Korea) at a speed of $150 \mathrm{rpm}$. At the end of the treatment, biosorbents were filtered by passing them through cloth coffee filters. The concentration of oil before and after treatment was calculated using the gravimetric method.

The percentage of oil removal and the uptake capacity of the biosorbent for each different oil concentration were calculated. The results were then used to decide which high and low concentration of oil will be used in RSM for optimization.

The percentage (\%) removal oil and amount of oil adsorbed by banana peel (qe) was calculated by equation (1) and (2), respectively:

$$
\begin{aligned}
& \text { Oil removal concentration }(\%)=\frac{100\left(C_{0}-C_{e}\right)}{C_{0}} \\
& q_{e}=\frac{\left(C_{0}-C_{e}\right)}{m} V
\end{aligned}
$$

where $C_{0}$ is the initial oil concentration $(\mathrm{mg} / \mathrm{L})$ and $C_{e}$ is the concentration of oil left $(\mathrm{mg} / \mathrm{L}), V$ the solution volume $(\mathrm{L})$ and $m$ is the mass of biosorbent (g). All adsorption experiments were duplicated and the mean values were used in data analysis.

\section{Experimental design and optimization using response surface methodology}

Three different parameters namely oil concentration $(0.5-10 \%)$, biosorbent dosage $(0.5-5 \mathrm{~g})$ and contact time ( $1-24$ hours) were selected as the critical variables. The experiments were randomly conducted and the measurements of percentage of oil removal for each experiment were calculated. A software package by Design Expert Version 6.0.8 was used to fit the second-order model. 
The effects of oil concentration, biosorbent dosage and contact time at three variable levels $(-1,0,1)$ in the reaction were evaluated in Table 1:

Table 1. Ranges of the factors investigated using Box-Behnken Design

\begin{tabular}{lcccc}
\hline \multirow{2}{*}{ Variables } & \multirow{3}{*}{ Symbols } & \multicolumn{3}{c}{ Levels } \\
\cline { 3 - 5 } & & $\mathbf{- 1}$ & $\mathbf{0}$ & $\mathbf{1}$ \\
\hline Oil Concentration (\%) & $\mathrm{A}$ & 0.5 & 5.25 & 10 \\
Biosorbent dosage (g) & $\mathrm{B}$ & 0.5 & 2.75 & 5 \\
Contact time (h) & $\mathrm{C}$ & 1 & 12.5 & 24 \\
\hline
\end{tabular}

To determine the relationship between the preparation variables and the responses under consideration, the data collected must be analysed by a statistical approach of using regression equations. For regression equation, the preparation variables were coded according to equation (3):

$$
y=\beta_{0}+\sum_{n}^{k} \beta_{i} x_{i}+\sum_{n}^{k} \beta_{i i} x_{i}^{2}+\sum_{n}^{k} \beta_{i j} x_{i} x_{j}+\varepsilon
$$

where $y$ is the response (dependent variables), $\beta_{0}$ is constant coefficient, $\beta_{1}, \beta_{i i}$ and $\beta_{i j}$ are the regression coefficients for linear, quadratic and interaction terms, respectively, whereas $x_{i}$ and $x_{j}$ are the independent variables, while $\varepsilon$ is the error [15].

\section{Screening of biosorbent for oil removal}

\section{Results and Discussion}

From the bar chart (Figure 1), UBP adsorbed oil more efficiently with the higher percentage oil removal of 31.63\%, whereas TBP with $5.675 \%$ of oil concentration. The surface activity of banana peels is mainly due to the presence of carboxyl, hydroxyl and amide groups on its surface and the high surface area of banana peels adds to the property and makes it an excellent and economic adsorbent, for water purification processes [16]. As shown by the result, UBP adsorbed better than TBP, so UBP was then used in RSM for the optimization process.

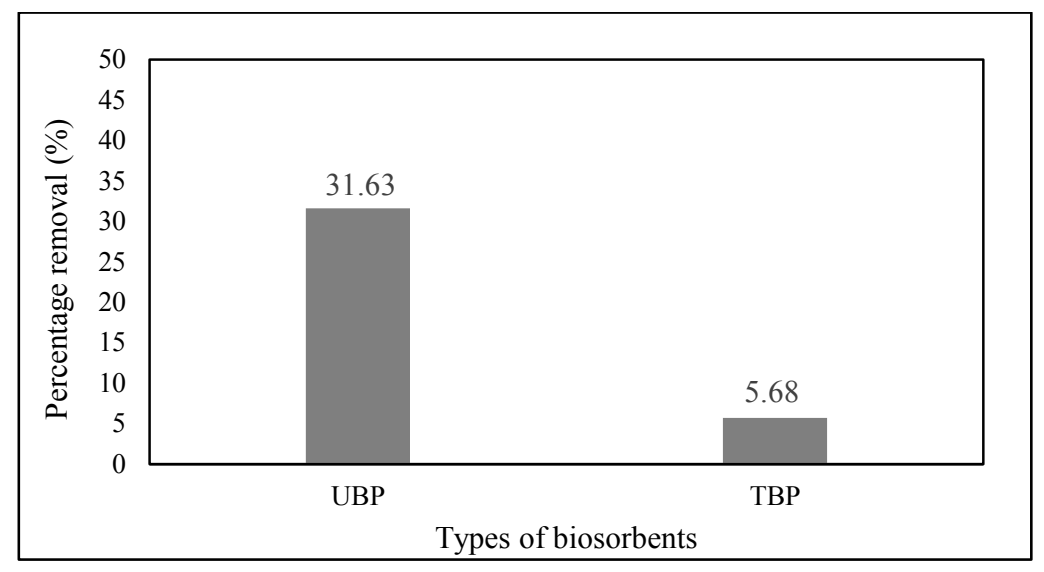

Figure 1. Percentage oil removal and uptake capacity of biosorbents

\section{RSM experiments and model fitting}

The results for the actual values acquired from the response from the experimental runs and the predicted values obtained from the generated quadratic model that corresponded to the percentage removal of oil are tabulated in Table 2. 
Table 2. Design of RSM and its actual and predicted values

\begin{tabular}{|c|c|c|c|c|c|}
\hline \multirow[b]{2}{*}{ Std } & \multirow{2}{*}{$\begin{array}{l}\text { Factor } 1 \\
\text { A: Oil Concentration } \\
(\%)\end{array}$} & \multirow{2}{*}{$\begin{array}{l}\text { Factor } 2 \\
\text { B: Dosage } \\
\text { (g) }\end{array}$} & \multirow{2}{*}{$\begin{array}{l}\text { Factor } 3 \\
\text { C: Time } \\
\text { (hour) }\end{array}$} & \multicolumn{2}{|c|}{ Percentage Oil Removal (\%) } \\
\hline & & & & $\begin{array}{c}\text { Actual } \\
\text { Value } \\
\end{array}$ & $\begin{array}{l}\text { Predicted } \\
\text { Value }\end{array}$ \\
\hline 1 & 0.5 & 0.5 & 12.5 & 65.72 & 66.91 \\
\hline 2 & 10 & 0.5 & 12.5 & 67.72 & 69.54 \\
\hline 3 & 0.5 & 5 & 12.5 & 63.72 & 61.89 \\
\hline 4 & 10 & 5 & 12.5 & 92.91 & 91.72 \\
\hline 5 & 0.5 & 2.75 & 1 & 19.57 & 23.59 \\
\hline 6 & 10 & 2.75 & 1 & 83.10 & 86.49 \\
\hline 7 & 0.5 & 2.75 & 24 & 94.29 & 90.89 \\
\hline 8 & 10 & 2.75 & 24 & 64.48 & 60.46 \\
\hline 9 & 5.25 & 0.5 & 1 & 79.47 & 74.25 \\
\hline 10 & 5.25 & 5 & 1 & 89.44 & 87.24 \\
\hline 11 & 5.25 & 0.5 & 24 & 97.10 & 99.29 \\
\hline 12 & 5.25 & 5 & 24 & 98.26 & 103.47 \\
\hline 13 & 5.25 & 2.75 & 12.5 & 88.91 & 91.48 \\
\hline 14 & 5.25 & 2.75 & 12.5 & 88.55 & 91.48 \\
\hline 15 & 5.25 & 2.75 & 12.5 & 92.58 & 91.48 \\
\hline 16 & 5.25 & 2.75 & 12.5 & 91.97 & 91.48 \\
\hline 17 & 5.25 & 2.75 & 12.5 & 95.38 & 91.48 \\
\hline
\end{tabular}

The maximum removal efficiency of oil was found to be $98.25 \%$. The best fitting model was established by a regression analysis. The following equation is a regression model with the experimental results in terms of coded factors:

$$
\begin{aligned}
Y= & 91.4756+8.1154 \mathrm{~A}+4.2906 \mathrm{~B}+10.3175 \mathrm{C}-22.324 \mathrm{~A}^{2}+3.3721 \mathrm{~B}^{2}-3.7837 \mathrm{C}^{2}+6.7993 \mathrm{AB}-23.333 \mathrm{AC}- \\
& 2.201 \mathrm{BC}
\end{aligned}
$$

where $Y$ is the percentage oil removal (\%), A is oil concentration (\%), B is the biosorbent dosage (g) and $\mathrm{C}$ is the contact time of biosorbent to oil (hour).

\section{Regression model and Analysis of Variance (ANOVA)}

Statistical testing of the model was performed with the Fisher's statistical test for analysis of variance (ANOVA), as shown in Table 3.

The significance of each model is assessed from the coefficient $\left(\mathrm{R}^{2}\right)$ which is found to be 0.97 . The high coefficient of determination between the predicted and experimental adsorption activities confirmed that the quadratic polynomial model was adequate to explain the actual relationship between the response and the significant variables.

The F statistic value of 29.63 implies that the model is significant and there is only a $0.01 \%$ chance that the model could occur due to noise. The significance of each term in this model is also evaluated by P value (Prob $>$ F) that was less than 0.05 . This was supported by a P-value which confirmed that the quadratic model was statistically significant and sufficient to explain the actual relationship between the response and the significant variables. 
Najaa Syuhada et al: RESPONSE SURFACE METHODOLOGY OPTIMIZATION OF OIL REMOVAL USING BANANA PEEL AS BIOSORBENT

Table 3. Analysis of variance for the response of the uptake capacity for cooking oil

\begin{tabular}{lrcrrr}
\hline Source & $\begin{array}{r}\text { Sum } \\
\text { Squares }\end{array}$ & $\begin{array}{c}\text { Degrees } \\
\text { Freedom }\end{array}$ & $\begin{array}{r}\text { Mean } \\
\text { Square }\end{array}$ & F Value & $\begin{array}{r}\text { Prob }>\text { F } \\
\text { (P-value) }\end{array}$ \\
\hline Model & 6127.18 & 9 & 680.80 & 29.63 & $<0.0001$ \\
$\mathrm{~A}$ & 526.87 & 1 & 526.87 & 22.93 & 0.0020 \\
$\mathrm{~B}$ & 147.28 & 1 & 147.28 & 6.41 & 0.04 \\
$\mathrm{C}$ & 851.61 & 1 & 851.61 & 37.06 & 0.0005 \\
$\mathrm{~A}^{2}$ & 2099.95 & 1 & 2099.95 & 91.39 & $<0.0001$ \\
$\mathrm{~B}^{2}$ & 47.88 & 1 & 47.88 & 2.08 & 0.20 \\
$\mathrm{C}^{2}$ & 60.28 & 1 & 60.28 & 2.62 & 0.15 \\
$\mathrm{AB}$ & 184.92 & 1 & 184.92 & 8.05 & 0.03 \\
$\mathrm{AC}$ & 2177.72 & 1 & 2177.72 & 94.78 & $<0.0001$ \\
$\mathrm{BC}$ & 19.38 & 1 & 19.38 & 0.84 & 0.39 \\
Residual & 160.84 & 7 & 22.98 & & \\
Lack of Fit & 128.91 & 3 & 42.97 & 5.38 & 0.07 \\
Pure Error & 31.93 & 4 & 7.98 & & \\
Corrected Total & 6288.02 & 16 & & & \\
\hline
\end{tabular}

$\mathrm{R}^{2}=0.98$, Coefficient of variation $=5.94$, Adj $\mathrm{R}^{2}=0.94$, Pred $\mathrm{R}^{2}=0.66$, Adeq precision $=21.73$

The ANOVA test indicates that the F-value for the lack of fit (5.38) was lower than the tabulated value, suggesting that the lack of fit was insignificant relative to the pure error, thereby indicating the data in the experimental domain was well represented by the model. There is a $6.68 \%$ chance that a "Lack of Fit F-value" this large could occur due to noise.

\section{Effect of process variables on the percentage removal of cooking oil}

Figure 2 below illustrates the effect of the process variables, namely oil concentration, biosorbent dosage and contact time on the percentage removal of cooking oil.

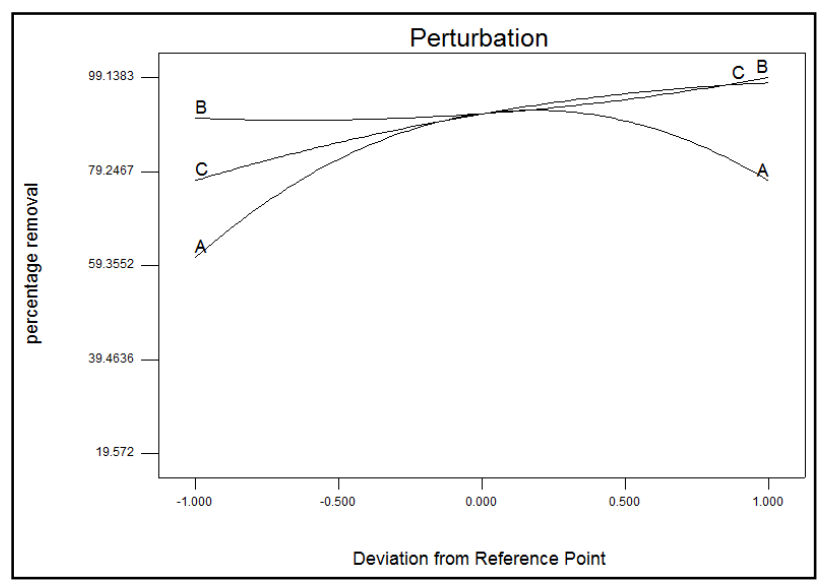

Figure 2. Deviation of reference point for the oil concentration, biosorbent dosage and contact time on the percentage removal of cooking oil 
The percentage removal of cooking oil increased at first but then decreased with the increase of (A) oil concentration, whereas the percentage removal of cooking oil showed an upward trend with the increase of (B) biosorbent dosage into the oil. From the figure, it can also be seen that the increase in $(\mathrm{C})$ contact time of biosorbent with oil also increased the percentage removal of oil.

\section{Effect of oil concentration and biosorbent dosage}

Figure 3 illustrates the response surface curve and contour plot for the oil concentration (A) and biosorbent dosage (B), and their mutual interaction on the percentage removal of cooking oil by UBP.

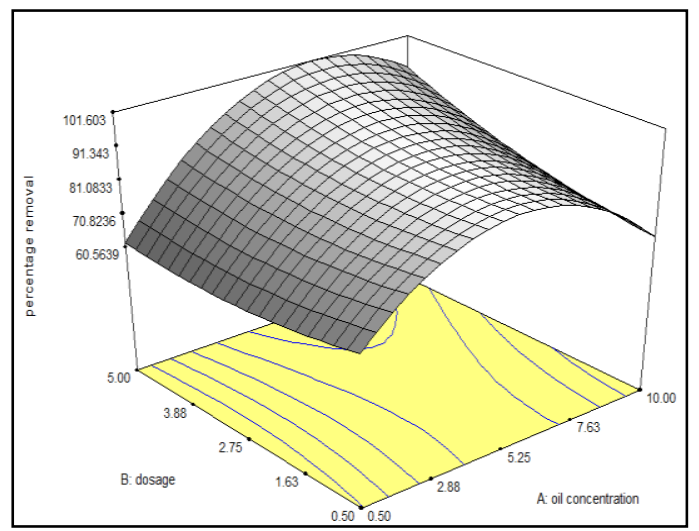

Figure 3. Effect of oil concentration (A) and biosorbent dosage (B) response surface plot on percentage removal of oil

It has been found that the efficiency of biosorbents to adsorb oil initially increases with increasing oil concentration. At lower oil concentrations in the solution, the oils would interact with the sorbent and thus facilitated adsorption whereas at higher concentrations, more oils are left un-absorbed in the solution due to the saturation of the binding sites [17].

The increasing initial oil concentration would decrease oil removal efficiency. This must be caused by the decrease in surface area of the biosorbent due to the increasing of the amount of oil adsorbed per unit weight of biosorbent [18].

At high initial concentration, the gradient between the solution sample and the center of particle enhances oil diffusion through the film surrounding the particle and in the porous network of the biosorbent. Eventually, as time goes by, the adsorbed oil will start to clog the pores near the outer surface so oil residue can no longer diffuse to the active sites deep within the interior surface [19].

\section{Effect of oil concentration and time}

Figure 4 illustrates the response surface curve and contour plot for the oil concentration $(\mathrm{A})$ and time $(\mathrm{C})$, and their mutual interaction on the percentage removal of cooking oil by UBP.

It was observed that the interactions of the two reaction parameters, oil concentration (A) and time (C) were significant because of the small p-value $(<0.0001)$ that is less than 0.05 . Increasing the contact time between the biosorbent and oil significantly elevated the percentage removal of oil. It can be concluded that the reaction time had a positive effect on percentage removal of oil. Hence, the prolonged contact time increased the probability of effective collisions between oil and biosorbent. In addition, at longer mixing time, breakage of the oil droplets are enhanced, thus reducing the diameter of the oil droplets (emulsification) which leads to more interfacial area for the adsorption to occur and encourages the adsorption of residue oil by biosorbent [19]. Therefore, interaction time between the oil molecule and biosorbent particles is very important in oil removal. 


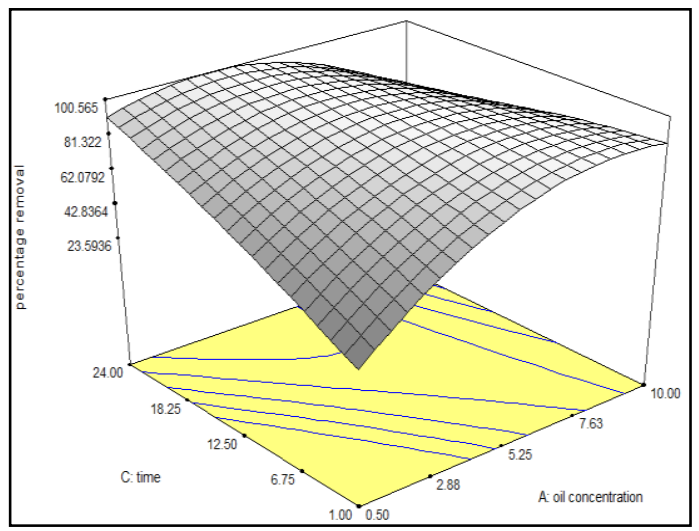

Figure 4. Effect of oil concentration (A) and time (C) response surface plot on percentage removal of oil

The increased rate of percentage removal of oil is due to the larger surface area of the biosorbents being available at the beginning of adsorption of oil. The increasing contact time increased the oil adsorption and it remains constant after equilibrium is reached [20]. However, contact time plays an important role only at the beginning of oil adsorption, and is less important near equilibrium. At near equilibrium, only a small increase in oil removal is observed due to limited availability of biosorbent surfaces for oil entrapment [13].

\section{Effect of biosorbent dosage and time}

Figure 5 illustrates the response surface curve and contour plot for the biosorbent dosage (B) and time (C), and their mutual interaction on the percentage removal of oil by UBP.

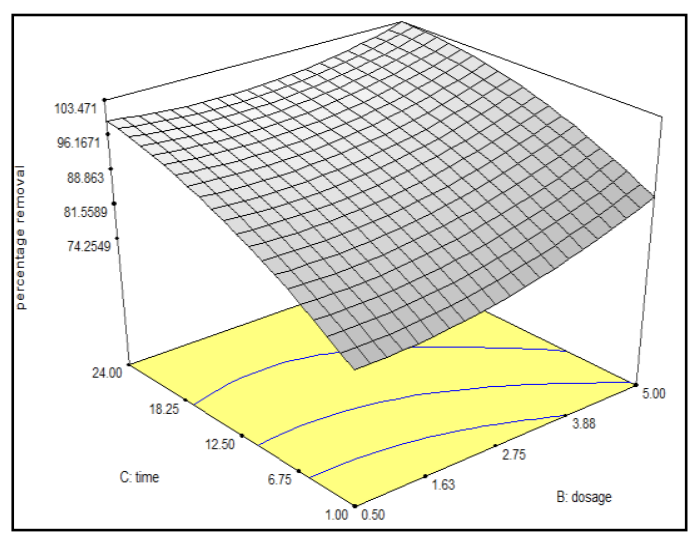

Figure 5. Effect of dosage (B) and time (C) response surface plot on percentage removal of oil

It could be noted that for both an increase in contact time and the biosorbent dosage, the percentage removal increases. An increase in biosorbent dosage results in more binding sites available for the oil molecules to be adsorbed, whereas, an increased contact time provides enough time for the molecules to bind on the adsorbent sites. Adsorption is a surface related phenomenon, at equilibrium most of the oil molecules were adsorbed on the surface and in the intermolecular pores of the adsorbent [21]. Hence, at higher dosage, the oil adsorbed are higher due to the availability of more empty binding sites as compared to lower dosages which has less binding sites to adsorb the same amount of oil in the adsorbate solution [17]. 
The increase in active sites will lead to a higher percentage removal but with lowered oil uptake per unit of adsorbent. This is due to the abundancy of active sites available on biosorbent for oil to be adsorbed at a higher dosage, thus leading to a higher interaction between oil particles and adsorbent [22]. However, saturated oil binding sites occurred with the increasing biosorbent dosage. In addition, saturation effect also reduces the efficiency of oil removal when maximum sorption capacity is reached [23].

\section{Optimum conditions and model verification}

The optimum condition for percentage of oil removal is shown in Table 4. The model capable of predicting the maximum adsorption capacity showed that the optimum condition for the oil removal were concentration of oil at $8.74 \%$, with a dosage of $4.94 \mathrm{~g}$ and a duration of 10.29 hours. Under these conditions, the predicted adsorption capacity was $99.18 \%$ which was in good agreement with the experimental value of $98.86 \%$.

The obtained results were found to be relatively close to the predicted percentage removal and this confirmed the eligibility of the quadratic model suggested by the software. Thus, RSM with appropriate experimental design could be effectively applied to optimize the process parameters in this investigation.

Table 4. Optimum conditions for percentage of oil removal

\begin{tabular}{lccccc}
\hline Number & $\begin{array}{c}\text { Oil Concentration } \\
(\mathbf{\%})\end{array}$ & $\begin{array}{c}\text { Dosage } \\
\text { (g) }\end{array}$ & $\begin{array}{c}\text { Time } \\
(\mathbf{h})\end{array}$ & $\begin{array}{c}\text { Actual Percentage } \\
\text { Removal (\%) }\end{array}$ & $\begin{array}{c}\text { Predicted Percentage } \\
\text { Removal (\%) }\end{array}$ \\
\hline 1 & 8.74 & 4.94 & 10.29 & 98.86 & 99.18 \\
\hline
\end{tabular}

\section{Conclusion}

The optimum conditions of UBP as oil adsorbent were obtained as follows; oil concentration $8.74 \%$, dosage $4.94 \mathrm{~g}$, time 10.29 hours. Under these optimum conditions, the predicted value from the model is $99.18 \%$ and the obtained result was $98.86 \%$ and this indicates the successful development model because of a small deviation error. Statistical optimization on UBP production was successfully performed using RSM via DOE software by conducting a BBD by varying the activation temperature and contact time.

UBP can benefit the oil pollution issue with a more affordable solution and this can also reduce the abundance of household waste problems. The use of UBP in oil removal needs to be further investigated to promote large-scale use of non-conventional adsorbents. The uses of UBP for wastewater treatment applications today are strongly recommended due to their local availability, technical feasibility, engineering applicability, and cost effectiveness. Undoubtedly, UBP can benefit commercial purposes in the future.

\section{Acknowledgement}

The authors acknowledge the Ministry of Higher Education (MOHE) and Universiti Malaysia Kelantan (UMK) for funding the project through NRGS Grant (R/NRGS/A0700/00413A/006/2014/000150).

\section{References}

1. Hebbar, A. H. and Jayantha, K. S. (2013). Oil and grease removal from wastewater using laterite as an adsorbent material. International Journal of Emerging Technology and Advanced Engineering, 3(5): 654 - 657.

2. Pawlak, Z., Rauckyte, T. and Oloyede, A. (2008). Oil, grease and used petroleum oil management and environmental economic issues. Journal of Achievements in Materials and Manufacturing Engineering, 26(1): $11-17$.

3. El-Nafaty, U. A., Muhammad, I. M. and Abdulsalam, S. (2013). Biosorption and kinetic studies on oil removal from produced water using banana peel. Civil and Environmental Research, 3(7): 125 - 136.

4. Volesky, B. and Holan, Z. R. (1994) Biosorption of lead and nickel by biomass of marine algae. Biotechnology and Bioengineering, 43 (11): $1001-1009$.

5. Vlaev, L., Petkov, P., Dimitrov, A. and Genieva, S. (2011). Cleanup of water polluted with crude oil or diesel fuel using rice husks ash. Journal of the Taiwan Institute of Chemical Engineers, 42(6): 957 - 964. 
6. Hussein, M., Amer, A. and Sawsan, I. I. (2009). Oil spill sorption using carbonized pith bagasse. application of carbonized pith bagasse as loose fiber. Global NEST Journal, 11(4): 440 - 448.

7. Cojocaru, C., Macoveanu, M. and Cretescu, I. (2011). Peat-based sorbents for the removal of oil spills from water surface: Application of artificial neural network modelling. Colloids and Surfaces A: Physicochemical and Engineering Aspects, 384 (1-3): 675 - 684.

8. Banerjee, S. S., Joshi, M. V. and Jayaram, R. V. (2006). Treatment of oil spill by sorption technique using fatty acid grafted sawdust. Chemosphere, 64(6): 1026-1031.

9. Brandao, P. C., Souza, T. C., Ferreira, C. A., Hori, C. E. and Romanielo, L. L. (2010). Removal of petroleum hydrocarbons from aqueous solution using sugarcane bagasse as adsorbent. Journal of Hazardous Materials, 175(1-3): $1106-1112$.

10. Said, A., Ludwick, A. G. and Aglan, H. A. (2009). Usefulness of raw bagasse for oil absorption: A comparison of raw and acylated bagasse and their components. Bioresource Technology, 100(7): $2219-2222$.

11. Annunciado, T. R., Sydenstricker, T. H. D. and Amico, S. C. (2005). Experimental investigation of various vegetable fibers as sorbent materials for oil spills sorbent materials for oil spills. Marine Pollution Bulletin, 50(11): $1340-1346$.

12. Yi, J., Wang, Z., Bai, H., Yu, X., Jing, J. and Zuo. L. (2015). Optimization of purification, identification and evaluation of the in vitro antitumor activity of polyphenols from Pinus koraiensis pinecones. Molecules, 20 (6): $10450-10467$.

13. Kadir, S., Matali, S., Mohamad, N. F. and Rani, N. H. A. (2014). Preparation of activated carbon from oil palm empty fruit bunch (EFB) by steam activation using response surface methodology. International Journal of Materials Science and Applications, 3(5): 159 - 163.

14. Yang, M. (2011). Produced water. Springer, Glasgow: pp. $57-88$.

15. Salamatinia, B., Zinatizadeh, A., Kamaruddin, A. and Abdullah, A. Z. (2006). Application of response surface methodology for the optimization of $\mathrm{Cu}$ and $\mathrm{Zn}$ removals by sorption on pre-treated oil palm frond (OPF). Iranian Journal of Chemical Engineering, 3(2): 73 - 84.

16. Singhal, S., Agarwal, S., Bahukhandi, K., Sharma, R. and Singhal, N. (2014). Bio-adsorbent: A cost-effective method for effluent treatment. International Journal of Environmental Sciences and Research, 3(1): 151 - 156

17. Abdel-Ghani, N. and El-Chaghaby, G. (2014). Biosorption for metal ions removal from aqueous solutions: A review of recent studies. International Journal of Latest Research in Science and Technology, 3(1): $24-42$.

18. Alkhalssi, R. M., Saeed, E. A. and Khalid, M. G. (2014). Treatment of emulsified oil in produced water from oil wells by adsorption on to corn-cob as sorbent. Nahrain University, College of Engineering Journal, 17(1): $83-90$.

19. Ahmad, A. L., Sumathi, S. and Hameed, B. H. (2005). Adsorption of residue oil from palm oil mill effluent using powder and flake chitosan: Equilibrium and kinetic studies. Water Research, 39(12): 2483 - 2494.

20. Kumar, P. S. and Kirthika, K. (2009). Equilibrium and kinetic study of adsorption of nickel from aqueous solution onto bael tree leaf powder. Journal of Engineering Science and Technology, 4(4): $351-363$.

21. Mohammed, S. A., Faisal, I. and Alwan, M. M. (2011). Oily wastewater treatment using expanded beds of activated carbon and zeolite. Journal of Chemical and Petroleum Engineering, 12(1): 13.

22. Sidik, S. M., Jalil, A. A., Triwahyono, S., Adam, S. H., Satar, M. A. H. and Hameed, B. H. (2012). Modified oil palm leaves adsorbent with enhanced hydrophobicity for crude oil removal. Chemical Engineering Journal, 203: $9-18$.

23. Rajakovic V., Aleksic, G. and Rajakovic, L. (2008). Governing factors for motor oil removal from water with different sorption materials. Journal of Hazardous Materials, 154(1-3): 558 - 563. 